\title{
Exploring the most influential papers in Vietnam's political economy in the past ten years
}

\author{
Ho Manh Toan \\ Centre for Interdisciplinary Social Research \\ Phenikaa University
}

Hanoi, 27-12-2020

This short explorative article looks at the list of papers on Vietnam's political economy in the past ten years.

The study used Google Scholar and the number of citations to determine the influential papers. "Vietnam's political economy," "Vietnam political economy," "Vietnamese politics and economy" are searched keywords. The results are presented in Table 1.

Table 1. Most cited papers from the Google Scholar database

\begin{tabular}{|l|c|c|c|}
\hline \multicolumn{1}{|c|}{ Paper } & Year & $\begin{array}{c}\text { Citations (as of } \\
\text { 27-12-2020) }\end{array}$ & Note \\
\hline $\begin{array}{l}\text { Vietnam's political economy: a } \\
\text { discussion on the 1986-2016 period }\end{array}$ & 2014 & 67 & {$[1]$} \\
\hline $\begin{array}{l}\text { Vietnam's political economy in } \\
\text { transition (1986-2016) }\end{array}$ & 2014 & 45 & {$[2]$} \\
\hline $\begin{array}{l}\text { The political economy of } \\
\text { development in China and Vietnam }\end{array}$ & 2014 & 102 & {$[3]$} \\
\hline $\begin{array}{l}\text { Competing legacies: rupture and } \\
\text { continuity in Vietnamese political } \\
\text { economy }\end{array}$ & 2012 & 11 & {$[4]$} \\
\hline $\begin{array}{l}\text { The political economy of industrial } \\
\text { development in Vietnam: Impact of } \\
\text { state business relationship on } \\
\text { industrial performance }\end{array}$ & 2015 & 21 & {$[5]$} \\
\hline $\begin{array}{l}\text { The political economy of food price } \\
\text { volatility: The case of Vietnam and } \\
\text { rice }\end{array}$ & 2016 & 10 & {$[7]$} \\
\hline $\begin{array}{l}\text { The political economy of food price } \\
\text { policy in Vietnam }\end{array}$ & 2014 & & \\
\hline
\end{tabular}




\begin{tabular}{|l|c|c|c|}
\hline $\begin{array}{l}\text { Scaling up rural sanitation in } \\
\text { Vietnam: political economy } \\
\text { constraints and opportunities }\end{array}$ & 2011 & 12 & {$[8]$} \\
\hline $\begin{array}{l}\text { Vietnam: Political economy, } \\
\text { marketing system }\end{array}$ & 2012 & 36 & [9] \\
\hline $\begin{array}{l}\text { The missing middle: A political } \\
\text { economy of economic restructuring } \\
\text { in Vietnam }\end{array}$ & 2017 & 11 & {$[10]$} \\
\hline
\end{tabular}

With this set of keywords, we can only find three papers with more than 40 citations since 2010. Notably, they were all published in 2014, so the number of citations can be compared easily. Secondly, it should be noted that papers [1] and [2] are two versions of an article. Paper [1] is a full-length working paper that is available on SSRN. Meanwhile, paper [2] is a shorter version of [1], published in Stratfor Worldview-a leading publication in geopolitical intelligence. So, only [3] is a conventional journal article paper.

Considering papers with more than ten citations, we have some more candidates [410]. Moreover, when changing the filter to 'Any time,' several classic works entered the picture: Gainsborough's book from 2003 (141 citations) [11], Popkin's 41-years-old book [12] with 2721 citations, or Quang and Kammeier's paper with 109 citations [11], and some others [13-16].

This short article only examines a small number of articles in Google Scholar, and the list is by no means exhaustive. For future studies, researchers should pay attention to several factors. Firstly, different keywords can provide completely different results. For instance, "Vietnam's political economy" and "Vietnam political economy" do not seem too different, but the apostrophe and possessive form make the computer read these two keywords differently.

Thus, a subtle difference like this should not be neglected. Secondly, in the case of papers [1] and [2], it is interesting that they do not show up in the first few pages when entering 'Vietnam political economy' into the Google Scholar's search box, especially without the quotation mark. We suspected because these papers are not conventional journal articles, they are not prioritized by Google Scholar. Indeed, papers in the political economy are not limited to conventional journal articles; there are also valuable working papers from famous institutes $[1,5,8,10]$. These papers attract many citations, too, and researchers should not forget these papers in any analysis.

\section{References}

[1] Vuong, Q. H. (2014). Vietnam's Political Economy: A Discussion on the 1986-2016 Period. CEB Working Papers Series, N¹4-010, Université Libre de Bruxelles, Brussels, Belgium.

[2] Vuong, Q. H. (2014). Vietnam's Political Economy in Transition (1986-2016). Stratfor The Hub: International Perspectives (May 27, 2014). Retrieved from 
https://worldview.stratfor.com/article/vietnams-political-economy-transition-19862016.

[3] Malesky, E., \& London, J. (2014). The political economy of development in China and Vietnam. Annual Review of Political Science, 17, 395-419.

[4] Sasges, G., \& Cheshier, S. (2012). Competing legacies: rupture and continuity in Vietnamese political economy. South East Asia Research, 20(1), 5-33.

[5] Vu-Thanh, T. A. (2015). The political economy of industrial development in Vietnam: Impact of state business relationship on industrial performance, 1986-2012. GEG Working Paper, (No. 2015/107).

[6] Fulton, M. E., \& Reynolds, T. (2015). The political economy of food price volatility: The case of Vietnam and rice. American Journal of Agricultural Economics, 97(4), 12061226.

[7] Hai, N. M., \& Talbot, T. (2014). The political economy of food price policy in Vietnam. Food Price Policy in an Era of Market Instability, 319-338.

[8] Harris, D., Kooy, M., \& Nam, P. Q. (2011). Scaling up rural sanitation in Vietnam: political economy constraints and opportunities. ODI Working Paper, (341).

[9] Shultz, C. J. (2012). Vietnam: Political economy, marketing system. Journal of Macromarketing, 32(1), 7-17.

[10] Busch, M. (2017). The missing middle: A political economy of economic restructuring in Vietnam. Lowy Institute for International Policy. Retrieved from http://hdl.handle.net/11540/7748.

[11] Gainsborough, M. (2003). Changing political economy of Vietnam: the case of Ho Chi Minh City. Routledge.

[12] Popkin, S. L. (1979). The rational peasant: The political economy of rural society in Vietnam. University of California Press.

[13] Quang, N., \& Kammeier, H. D. (2002). Changes in the political economy of Vietnam and their impacts on the built environment of Hanoi. Cities, 19(6), 373-388.

[14] Gainsborough, M. (2004). Key issues in the political economy of post-doi moi Vietnam. Rethinking Vietnam, 40-52.

[15] Beresford, M., \& Fraser, L. (1992). Political economy of the environment in Vietnam. Journal of Contemporary Asia, 22(1), 3-19.

[16] London, J. D. (2006). Vietnam: The political economy of education in a "Socialist" periphery. Asia Pacific Journal of Education, 26(1), 1-20. 